\title{
2. Engagement in play, engagement in politics: Playing political video games
}

\author{
Joyce Neys and Jeroen Jansz
}

\begin{abstract}
It is a widely shared value in Western democracies that citizens should engage with political and social issues. This engagement is not necessarily confined to party politics, but includes other aspects of citizenship as well, from commitment to a local cause to supporting the global campaign of an NGO. Video games are arguably an excellent platform for encouraging and developing such engagement. Playing may facilitate civic engagement by allowing players to practice and experience different civic competencies in the safe environment of the game. This chapter discusses the results of research in this up-and-coming field and critically assesses those results in light of the opportunities this form of play might offer citizens when negotiating contemporary forms of citizenship.
\end{abstract}

Keywords: Civic engagement, citizenship, media, play, serious games, persuasive gaming

This chapter explores whether playing political video games can facilitate civic engagement and, if so, how it encourages political participation. Over the last several decades, there has been an increasing academic focus on the diverse properties, characteristics, effects, and consequences of games and gaming. The research spans across a wide variety of topics that range from addiction and other negative effects of excessive gaming, to a focus on simulation from a design and educational perspective, to the beneficial effects of games in relation to health issues (e.g. revalidation and exergames). These topics have been scrutinized from different perspectives. Games have been analyzed from an economic perspective (focusing on the multimillion-dollar game industry), a psychological perspective (addressing

Glas, R., S. Lammes, M. de Lange, J. Raessens, and I. de Vries, eds. 2019. The Playful Citizen. Civic Engagement in a Mediatized Culture. Amsterdam: Amsterdam University Press. DOI: $10.5117 / 9789462984523 / \mathrm{CHO} 2$ 
a wide range of motivational questions), an educational perspective (where games are studied in the context of formal and informal learning), and a cultural perspective (where games are studied as cultural artifacts of play) (Raessens and Goldstein 2005; Ritterfeld, Cody, and Vorderer 2009). In other words, the field of game studies is maturing and is thus providing additional knowledge that contributes to a better understanding of the relationship between gaming and culture. We see, slowly but surely, the field moving away from the bad versus good debate and starting to ask the bigger questions: how and in what settings can games best be used to what end?

The immense global popularity of playing video games is one important instance of what Raessens has called "the ludification of culture" $(2006,2014)$. However, ludification is by no means confined to playing (entertainment) games as playfulness increasingly penetrates different cultural domains (Frissen et al. 2015, 9). For example, leisure time (fun shopping), work (presenting repetitive tasks in a playful manner), and school (edugames). In this chapter, we will focus on the political domain. We aim to investigate whether and, if so, how citizens might become engaged in politics by playing (political) video games. We will discuss both games that purposively communicate a political message, as well as games with more indirect political implications.

The chapter starts by exploring contemporary notions of citizenship and what that entails in today's (Western) democracies. Related to the shifting conceptualization of citizenship, or what it means to be a good citizen, the changing media landscape is briefly discussed, after which we zoom in on games. We then move to discuss the wider notion of play in relation to engagement and how there are indications slowly starting to emerge that games are an excellent tool to engage (young) people, also in more political matters, even though it also becomes clear that 'true' engagement, or extended and substantial change in political interest/engagement, is always the product of the dynamic between playing such a game (the game as first contact and instigator) and the player's discussion about the (contents of the) game with his/her peers. We argue that this might be explained by political socialization theory (see also Lin et al. 2010; Bourgonjon and Soetaert 2013), which leads to the conceptualization of games as one form of socializing agent. 


\section{The good citizen is an active citizen: Citizenship in the twenty-first century}

It is a widely shared value in Western democracies that citizens should engage with political and social issues. This is deemed necessary in order to maintain a healthy functioning democracy, since democracies thrive when citizens are active agents and participate in public debate informing themselves about issues relevant to them in particular and society in general. It is often argued that this informational prerequisite is required in order for citizens to make well-informed decisions in more formal electoral processes and to be able to fully participate in society (Ekman and Amnå 2012). This full participation entails, among other things, voting in local and national elections, being able to identify that a neighbor might need help, and knowing where to go when there is a problem in one's community. In other words, it is expected that citizens know their rights and responsibilities and that they are able to act upon those when necessary. Therefore, being a 'good citizen' relates to the functioning of political and electoral processes (e.g. making an informed decision when voting) also on a societal level (e.g. being concerned with civic issues both on local and national level).

In other words, in order for a democracy to flourish it heavily depends on the civic virtues and the engagement of its citizens (Verba, Schlozman, and Brady 1995; Honohan 2002; Schols 2015). This civic engagement of the active citizenry can roughly be described as all actions that any individual citizen undertakes to change something for the better that affects not just him- or herself, but also the broader community he or she is part of. These actions can, for example, be described as, but are not limited to, volunteering to help out other people in need, taking part in a demonstration for equal rights or signing a petition to help free a fellow citizen from wrongful imprisonment. Citizens speaking up and being concerned with their communities and social surroundings benefits democracy overall. The formal institutes of power, like for example the government, are thus made accountable and, as such, are forced to listen to the people, which, in turn, guarantees quality of government and a healthy and thriving democracy.

What this means in practical terms has been, in particular in the last decades, reason for heated debates, both in- and outside of academia (Dahlgren 2006, 2009). For most Western democracies, active citizenship used to be described via participation in more formal institutions or volunteer work, but also membership in a political party. This tendency is also reflected in academic research that has measured the degree of good and active citizenship using the aforementioned characteristics. For over a decade, for 
example, the authoritative International Social Survey Program (ISSP) has used four categories of citizenship to assess what good citizenship should entail according to respondents: Participation (e.g. importance of voting and being active in politics); autonomy (e.g. being able to form one's own opinion); social order (e.g. obeying the law); and solidarity (e.g. supporting people who are worse off) (see also Dalton 2008). These surveys are used worldwide, both nationally (e.g. the General Social Survey in the United States) and internationally (e.g. the European Social Survey).

However, these questions mainly address the normative conceptualizations of the 'good citizen' according to citizens themselves. It describes, in other words, what a 'good citizen' should be doing and not what citizens actually do. And while there is a predictable discrepancy between citizens' civic values and their actual behavior, expressions of these values were seen to be rather stable. Up until about the start of the twenty-first century, in most Western democracies civic values relating to social order were valued to be more important to good citizenship than any others (Dalton 2008). This duty-based citizenship expresses itself in the acts citizens perform in relation to society (as the community of citizens). Among these social acts, political party membership was relatively high, as was union membership, as well as the self-evident duty to vote in elections.

Increasingly, however, there have been signs that citizens seem to be participating less, at least in these formal institutions (Kerr et al. 2009). A research study by Hoskins, Villalba, and Saisana (2012) shows that younger generations particularly lack the civic competences needed to be(come) successful active citizens and that these competences have been in decline over the past several decades among European youth. These results are in line with previous research that signals a steady decline in civic engagement in general and political participation in particular over the course of the last half century (e.g. Craig 1996; Levine and Lopez 2002; Lopez and Donovan 2002; Wattenberg 2002). Most known in this respect is perhaps Robert Putnam's work Bowling alone, in which he argues that "declining electoral participation is merely the most visible symptom of a broader disengagement from community life" $(2000,35)$, but he is surely not alone in this analysis (e.g. Kaase and Newton 1995; Norris 2002).

However, with the increase in main stream internet access in most Western democracies around the turn of the century, quite a few opposite readings of the state of democracy started to emerge. Rather than seeing a decline in engagement and participation, some scholars started to recognize a fundamental change in the way citizens engage and actively participate. In particular, online participatory practices were celebrated (e.g. Jenkins 
2006; Jenkins and Carpentier 2013; Thorson et al. 2013; Kligler-Vilenchik and Shresthova 2014; Jenkins, Ito, and boyd 2016). It has been acknowledged that patterns of engagement and participation that are visible offline can also be seen online (e.g. Smith 2013; Gainous and Wagner 2014), so enthusiasts remain confident in their argument that democracy is thriving. They point out that young people increasingly show high levels of participation and engagement, but that they show this in different ways than before (e.g. Stolle and Hooghe 2005; Rainie et al. 2012; Schols 2015).

These different ways of participating and engaging with political and civic matters were for a long time not regarded as political practices. This might be one way to understand the contrasting readings of the state of democracy as outlined above. More recently, however, these different approaches are beginning to be reflected at the conceptual level with changes in the measurement of political participation and civic engagement. Joakim Ekman and Erik Amnå (2012), for example, propose a new typology for participation and engagement that makes a clear distinction between manifest (i.e. political participation including formal political behavior) and latent (i.e. civic engagement and social involvement) forms of participation. The idea of latent forms of participation is especially crucial in understanding these newer forms of political behavior.

A more fundamental explanation of the aforementioned contradictory results might be to take generational differences into account regarding the very notion of what citizenship entails. In other words, what it means for citizens to be a 'good citizen' changes and has been changing over the last several decades. This is best reflected in a shift in people's views concerning the importance of the different civic values discussed earlier. Rather than emphasizing the importance of contributing to and interacting with democracy's formal institutions (reflected in party memberships, for example, which translates into a dutiful form of citizenship), it has become increasingly important, especially but not only for younger generations to express their political and civic engagement in different ways (Bennett 2008; Bennett, Wells, and Freelon 2011). Dalton (2008) refers to this as the difference between dutiful and engaged citizenship, also referred to as allegiant and assertive citizens (Dalton and Welzel 2014). Interestingly, this is also reflected in a change in the importance of civic values. So-called allegiant citizens value social order more (e.g. obeying the law), while assertive citizens place more importance on autonomy (e.g. being able to form your own opinion in your own way) and solidarity (e.g. supporting those who are worse off) as markers of good citizenship (Hoskins, Villalba, and Saisana 2012). 
Additionally, Chouliaraki (2010) argues that citizenship should be conceptualized as expressing oneself in public. This seems increasingly relevant with more opportunities to express oneself and engage online. Self-mediation in this sense might be at the core of engagement and participation and lead to new forms of playful citizenship. She states that:

This mediated participation of ordinary people in public culture is being hailed as blurring traditional boundaries between media producers and consumers, and leading to new forms of playful citizenship, critical discourse and cosmopolitan solidarity. Drawing on a view of self-mediation as a new terrain of democratisation that is, however, embedded within the regulative regimes of the market or the state, [we should] critically explore the dynamics of mediated participation as an ambivalent discourse that is shifting the sensibilities and practices of citizenship. (Chouliaraki 2010, 227)

For Chouliaraki $(2010,3)$, the ability to express yourself in order to make yourself visible and audible is key here. Therefore, creating and sharing content online constitutes an act of citizenship and should be considered as a form of citizen performance and voicing. In this sense, the changing media landscape, particularly the rise of the gaming industry, most definitely plays a significant role in the further exploration of playful citizenship.

\section{Media landscape: Games as socializing agents and informal contexts}

Games have increasingly been the focus of academic research and the field of game studies has matured over the last two decades (Raessens 2016). Game studies as an interdisciplinary field examines games from a communicative, psychological, design, and Humanities perspective approaching games as simulations, representations, and cultural artifacts (e.g. Le Diberder and Le Diberder 1998; Aarseth 2001; Frasca 2003b; Raessens and Goldstein 2005; Bogost 2007). Games are and have been celebrated for the specific properties they bring to the table. These characteristics seem to be particularly beneficial in settings where a player wishes to explore and experiment while also being able to experience the consequences that his or her choices might have (Jansz 2005; Squire 2007; Neys and Jansz 2010).

Games offer "a set of experiences a player participates in from a particular perspective, namely the perspective of the character or characters 
the player controls" (Gee 2007, 23). Within a game, the player often has to achieve certain goals to progress further. Players can decide on their own how to achieve these goals by making their own choices (within a certain framework). There is also a system of immediate feedback in place that tells the player (in more or less clear terms) what the consequences of their actions are and how these might be improved. In this way, games in general encourage players to interpret their experiences in certain ways and to seek explanations for their errors and expectation failures. Additionally, the practice of gaming is often set in a social setting as well. It is not uncommon for players to seek each other out and to discuss strategies or to solve problems related to the game (sometimes referred to as 'augmented play,' see Ito et al. 2009). As a result, the social network around the game is equally important in the overall gaming experience as the game play itself (Squire and Jenkins 2003; Gee 2007). The medium of the game can, in this sense, be regarded as a socializing agent.

The positive effects of playing games have been established in many different domains. These include, for example, increasing students' motivation to learn in a school environment, the acquisition of more expert knowledge and digital skills, as well as improving the performance of surgeons (Lieberman 2006; Ritterfeld and Weber 2006; Gee 2007; Goris, Jalink, and Ten Cate Hoedemaker 2014). There are three reasons usually given for these effects. The first focuses on the entertaining properties of games: games are perceived as "possibly the most engaging pastime in the history of mankind" (Prensky 2005, 101). The second factor concerns the interactive nature of games: playing a digital game is impossible without the active involvement of the players (Cover 2006). Consequently, players must pay attention to what they are doing and what they see on their screens. Gonzalo Frasca (2003b) points out that this means games offer distinctly different rhetorical possibilities; games offer different tools for conveying opinions and feelings than do more traditional media that depend heavily on the mechanism of narrative representation. Games, in contrast, mostly rely on the mechanism of simulation. This also becomes clear when considering the third point. The truly unique properties of games arguably lie in their expressive power. According to Bogost (2007), digital games are an expressive medium. They visually represent how real and imagined systems work and invite their players to interact with those systems in a playful manner. The capacity of games to reveal complex situations (Mitgutsch 2011b) in a relatively simple and often fun way is what distinguishes this medium from other, more traditional, media forms (see also Corbeil 1999). 
However, while there gradually seems to be an increasing academic interest in the uses and effects of games in different areas of people's lives, to date little attention has been given to the opportunities games might offer in relation to politics and citizenship. A notable exception is the research by Kahne, Middaugh, and Evans (2009), which explores the civic potential of video games in general. They argue that "gaming might foster civic engagement" $(2009,6)$. Since their focus is on the civic dimensions of video game play among young people, they have investigated what games have to offer youth regarding civic and political engagement compared to more traditional classroom settings. They find many parallels both in the structural form of the medium of the game (e.g. possibilities for some sort of simulation of part(s) of the political process and tools that facilitate collaboration and mentoring) as well as in the content of some games (e.g. learning how certain democratic processes work, learning about a particular event (war) or social issue (poverty), how to debate and share and form one's own opinion). Following Dewey's conceptualization of the democratic community, Kahne and his colleagues argue that games can be considered such places as well. This is particularly the case with the increase of participatory culture as described by Jenkins (2006) and Kligler-Vilenchik and Shresthova (2012). In this way, games can be seen as "places where diverse groups of individuals with shared interests join together, where groups must negotiate norms, where novices are mentored by more experienced community members, where teamwork enables all to benefit from the different skills of group members, and where collective problem-solving leads to collective intelligence" (Kahne, Middaugh, and Evans 2009, 6-7).

Moreover, there has also been research on the civic potential of Massive Multiplayer Online Role-Playing Games, or MMORPGs, such as Blizzard Entertainment's World of Warcraft (e.g. Steinkuehler 2005; Curry 2010), as a 'third place' for civic development. The results of these studies seem to confirm previous findings that playing such games may help develop collaboration and leadership skills in general (Whitton and Hollins 2008; Jang and Ryu 2011) and willingness to help (Peng, Lee, and Heeter 2010). Furthermore, Raphael et al. (2010) suggest in their study that the "most effective games for civic learning would be those that best integrate game play and content, that help players make connections between their individual actions and larger social structures, and that link ethical and expedient reasoning" $(2010,199)$ to spark ethical reflection among their players. In addition, they obtained similar results as Kahne, Middaugh, and Evans (2009), who focused on how different civic skills were practiced and learned through gameplay (Raphael, Bachen, and Hernández-Ramos 2012). 
The playful environment and social structure that the medium of the game offers is particularly relevant in this respect. In line with political socialization theory, when considering the game as a socializing agent, this medium can be regarded as one of the most important influences on how young people learn civic skills and engage in civic activities beside family and school. These finding are also supported the research of Bourgonjon and Soetaert (2013) as well as Lin and her colleagues (2010). This is especially relevant when we take into consideration the aforementioned shift, especially among younger people, toward more engaged forms of citizenship that value expression, autonomy, and solidarity more highly as traits of good citizenship.

Of particular interest in light of this chapter are games that are specifically aimed at affecting some sort of social change, that is, some form of attitudinal or behavioral change with their players. While such games have been studied for some time, it is only recently that this subdomain has required significant academic attention. Usually referred to as serious games, ${ }^{1}$ they can be defined as games that aim to do more than entertain only (Ritterfeld, Cody, and Vorderer 2009, 6; Bellotti et al. 2013). The creator of the game specifically intends the game to be more than just entertainment, he wants it to inform even more, or even persuade the player in a playful yet serious manner.

\section{Political video games: Games with an impact ${ }^{2}$}

Ian Bogost (2007) coined the term persuasive games as a response to the dichotomy (still commonly used) of entertainment games versus serious games. He argues that the aforementioned terminology wrongfully suggests that entertainment games are not suited to communicating serious messages (i.e. to be used for something other than just mere entertainment). Moreover, the term 'serious games' alludes to an almost exclusive focus on game content, rather than on the process of communication of the specific medium. This procedural aspect of gaming is what allows for the communication of serious information in such a unique way. The term 'persuasive gaming' reflects the centrality of this procedural rhetoric while at the same time focusing on those games that challenge given norms and worldviews. As

1 This specific delineation from entertainment games, particularly trying to define what these serious games are not, has left the field of game studies with a myriad of different terms that aim to capture this difference (e.g. games for change, social games, political games, etc.). For the purpose of this chapter, we will refer to such games as serious games or, when discussing the specific subfield of interest, political games.

2 Parts of this section have appeared, slightly altered, in an earlier publication, namely Neys (2014). 
such, the intent of the creator of the game to persuade the player is also important in defining it as a persuasive game (De la Hera 2017).

There are many different forms of persuasive games addressing different topics and developed by different stakeholders. There are games that focus on health issues, e.g. Re-Mission (Realtime Associates 2006), which shows children undergoing cancer therapy the importance of adhering to their medical treatment programs; on social awareness or advocacy, e.g. McDonald's Video Game (MolleIndustria 2006), which is concerned with the meat industry and its negative impact on society; on humanitarian crises, e.g. Darfur is Dying (interFUEL 2006), which deals with the famine in Darfur and its effect on local families; or games that promote a particular company or organization, called 'advergames.' The military makes use of these types of games as well, both for recruiting and instruction. America's Army (2002) is probably the most successful and well-known example in this regard. The United States Army, developer of the game, claimed a significant increase in recruitment information requests due to this game alone (Huntemann and Payne 2010).

The political subgenre of these persuasive games specifically focuses on games that challenge certain political stances or worldviews or address political issues. In order to fully appreciate and understand the different games available within this subgenre, the different parties that can develop such games should be taken into account alongside the topic or issue they address. This differentiation mainly happens in three dimensions: political institutions (such as political parties), non-profit organizations (such as the United Nations or HopeLab), and individuals.

Now that we have defined political video games and the theoretical background is set, we can explore and situate the empirical findings in this field and try to understand whether or not this form of play might offer citizens new and different ways of engaging in politics.

\section{Playing political video games: Civic engagement and political participation}

While the subgenre of political video games is small, the field is diverse in terms of the type of games it has to offer. And while The Cat and The Coup (Brinson and ValaNejad 2011) and Endgame: Syria (GameTheNews 2013) are two of the few relatively recent examples, it is not surprising that, as most of these games are created in the West (primarily in the United States or Western Europe), so the little research that has been conducted in this field also stems from these regions. 
At the turn of the century, the first political video games started to appear. Several games emerged particularly in the aftermath of the terror attacks in New York on 9/11 2001. A good example is September 12th by Gonzalo Frasca (2003a). The game shows a market square where citizens and terrorists can be seen walking around. The player has the choice to shoot rockets at the market to kill the terrorists. However, a shot, no matter how well aimed, always results in civilian casualties, which, in turn, leads to some of the grieving survivors turning into terrorists as well. The intent of the creator was to inform players of the importance of a political stance (such as, that violence will only generate more violence) and to make them reflect on this issue, much like political cartoons (Bogost 2006; Neys and Jansz 2010).

After 2004, political video games became a true, albeit small, subgenre. This mainly had to do with the emergence of political video games during the political campaigns for the United States general elections. In that year, The Howard Dean for Iowa Game (Persuasive Games 2003) was developed by the American Democratic Party; it was one of the first games commissioned for the United States general elections and, as such, added to the overall success of Howard Dean in harnessing the potential use of the internet for campaigning. Its aim was to help supporters of Howard Dean to understand grassroots outreach and to encourage them to participate in pre-caucus campaigning in Iowa.

Bogost (2006) advocates the analysis of the games themselves in order to scrutinize their use of procedural (rather than verbal) strategy to convey their messages. His work is important for the field of game studies in that it recognizes the subgenre of political video games as persuasive media. It is only after this work emerged that slowly the first exploratory studies started to appear that focus on citizens' responses to such games and have adopted the practice of gaming as the main focus of their research.

After just over a decade of research, the general tenure of these studies overall is positive. There is some evidence that suggests that playing political video games contributes to an increase in political participation and civic engagement (Neys and Jansz 2010; Waddington 2013). After playing political games, players indicate that they have become more engaged with the topic discussed in the game and have obtained more knowledge about the subject. They also indicate their intent to participate in more formal ways, for example by contacting an interest group (Neys and Jansz 2010). Jacobs (2016) studied My Cotton Picking Life (Rawlings 2012) about child labor in the cotton industry, comparing the effects of the game with those of a video clip covering the same issue. He found that playing the game had a stronger effect than watching the clip when experiencing the workload of 
the children. In their study about Darfur is Dying, Peng and her colleagues (2010) observed that people's willingness to help increased after playing. They compared video game play with text and video about the same topic, namely the famine in Darfur. They concluded that, when compared to the other two media formats, "playing [the game] resulted in greater willingness to help and greater role-taking” (Peng, Lee, and Heeter 2010, 735).

The effects on social behavior are especially evident when people talk with friends and family about the issues addressed in the game. This is also referred to as "social facilitation" (Neys and Jansz 2010) or "civic talk" (Klofstad 2011). This relates back to conceptualizing such games as socializing agents that play a role in the political socialization of their players. In other words, it shows that the effects and impact of playing these games should always be set in the context of everyday life, and not be regarded as isolated events. Raessens (2015) concurs with this point of view in his analysis of Darfur is Dying and Food Force (Deepend 2005). The focus of his analysis is conceptual rather than empirical. He argues that the game experience of being 'co-creator' results in a "forceful discursive space and practice, with real enough power to influence the terms in which people think, feel and act" $(2015,258)$.

This becomes even more apparent when looking at longer term effects, as illustrated by our own research (Neys et al. 2012) on Poverty Is Not a Game (iMinds 2010). This game was developed by the European Union in relation to the European year against poverty and social exclusion (see also Grove et al. 2012). The game aims to raise awareness and to discuss the complex mechanisms underlying poverty, especially among youth. The study questioned players immediately after playing the game and again three months later through self-report measures. As was expected, the intended political behavior measured immediately after playing scored higher than the actual political behavior after three months.

The results point toward the indirect effects of playing: the player's interest in and engagement with the topic in question (poverty) increased and, as such, had an indirect effect on participation. About one third of the players indicated that they had become more politically interested after the three months period. In fact, while these players indicated at the time of the first measurement that they were not politically interested, after three months they self-reported that they had become politically interested. Further investigation of this particular group showed that, again, social facilitation or civic talk was what appeared to be important for this process (Neys et al. 2012). While it is impossible to make any causal claims about what caused this positive change in political interest, research shows that it was this same group that indicated they had talked with their family and 
peers about the subject of poverty the most. Playing the game can then be regarded as the instigator, while talking might have, at least partly, facilitated an increase in political interest or at least facilitated a change in perception about whether or not players identify as politically interested. Playing the game arguably transformed players' understanding of their world in relation to the topic discussed in the game. Ruggiero (2015) observed a sleeper effect in her longitudinal study among players of Spent (McKinney, Urban Ministries of Durham 2011), a game about homelessness. The game did not have an effect immediately after playing, but when the participants were tested again three weeks later, the players held more favorable attitudes toward homelessness than those who did not play. Apparently, playing the game resulted in prolonged reflection on its subject matter.

This kind of transformative learning is exemplary for how games work. According to Konstantin Mitgutsch (2011a), this shows the distinctive power of games when compared to more traditional media. However, while academic research into game features, and the workings and mechanisms of (serious) games are increasing (e.g. Bellotti et al. 2013; Jacobs, Jansz and De la Hera 2017), the field is not currently able to make more authoritative claims about the way political video games do or do not engage their players in the long run.

\section{Conclusion}

This chapter has explored whether playing political video games can facilitate civic engagement and, if so, how it encourages political participation. While research is still scarce in this particular niche field of game studies, we can conclude in general that most, if not all, research generated positive results. Playing games in general, and political games in particular, does seem to facilitate some form of engagement and participation.

After discussing the first studies conducted on the issue of political games, we can carefully conclude that people do seem to become engaged with the topic or issue dealt with in the game after playing. It does seem to be the case, however, that these effects are of a transformational nature, meaning that "the perceived and achieved learning in the game and the contextualized and framed learning experience made through playing the game are transferred" (Mitgutsch 2011b, 51). The experiences in the game over time get applied to real life contexts and in this way, affect the player. The research so far suggests that the process of social facilitation is important in this respect, namely talking with friends and peers about the issue dealt 
with in the game (Neys and Jansz 2010). In this way, the game functions as an instigator where players reflect on the issue in terms of what it means to them personally. As such, games can be considered as socializing agents. This makes sense as, after all, games and gaming are part of everyday life.

It is evident, however, that more research is needed in this field. Longitudinal research should further investigate the long-term effects, while more comparative research is necessary to investigate the differences between games and other media. Representative and larger samples of players will also help in validating the first conclusions that were drawn here. It is also important to determine exactly who plays these games and if only people play such games that are already interested in politics. There are some promising indications that playing political games might also benefit those who do not think of themselves as politically interested. This challenging question is the topic of further investigation in this young and promising field which can shed light on contemporary forms and expressions of citizenship.

\section{Acknowledgments}

This research is part of the project Persuasive gaming. From theory-based design to validation and back, funded by the Netherlands Organisation for Scientific Research (NWO; 2013-2018; project number 314-99-106).

\section{References}

Aarseth, E. J. 2001. Computer game studies, year one. Game Studies 1 (1):1-15. Bellotti, F., B. Kapralos, K. Lee, P. Moreno-Ger, and R. Berta. 2013. Assessment in and of serious games: An overview. Advances in Human-Computer Interaction 2013:1-11.

Bennett, W. L. 2008. Changing citizenship in the digital age. In Civic life online: Learning how digital media can engage youth, ed. W. L. Bennett, 1-24. Cambridge, MA: The MIT Press.

Bennett, W. L., C. Wells, and D. Freelon. 2011. Communicating civic engagement: Contrasting models of citizenship in the youth web sphere.Journal of Communication 61 (5): 835-856.

Blizzard Entertainment. 2004. World of Warcraft. [Windows/OS X]. Blizzard Entertainment. Game.

Bogost, I. 2006. Unit operations: An approach to videogame criticism. Cambridge, MA: The MIT Press. 
—. 2007. Persuasive games: The expressive power ofvideogames. Cambridge, MA: The MIT Press.

Bourgonjon, J., and R. Soetaert. 2013. Video games and citizenship. CLCWeb: Comparative Literature and Culture 15 (3). http://docs.lib.purdue.edu/ clcweb/voli5/iss3/8.

Brinson, P., and K. ValaNejad. 2011. The Cat and the Coup. [Windows]. Game. Chouliaraki, L. 2010. Self-mediation: New media and citizenship. Critical Discourse Studies 7 (4): 227-232.

Corbeil, P. 1999. Learning from the children: Practical and theoretical reflections on playing and learning. Simulation and Gaming 30 (2): 163-180.

Cover, R. 2006. Audience inter/active: Interactive media, narrative control and reconceiving audience history. New Media and Society 8 (1):139-158.

Craig, S. 1996. Broken contracts: Changing relationships between Americans and their government. Boulder, CO: Westview Press.

Curry, K. 2010. Warcraft and civic education: MMORPGs as participatory cultures and how teachers can use them to improve civic education. The Social Studies 101 (6): 250-253.

Dahlgren, P. 2006. Doing citizenship: The cultural origins of civic agency in the public sphere. The European Journal of Cultural Studies 9 (3): 267-286.

-.2009. Media and political engagement: Citizens, communication and democracy. New York: Cambridge University Press.

Dalton, R. J. 2008. The good citizen: How a younger generation is reshaping American politics. Washington, DC: Congressional Quarterly Press.

Dalton, R. J., and C. Welzel, eds. 2014. The civic culture transformed: From allegiant to assertive citizens. New York: Cambridge University Press.

De Grove, F., J. van Looy, J. Neys, and J. Jansz. 2012. Playing in school or at home? An exploration of the effects of context on educational game experience. E-Journal of e-Learning 10 (2): 199-208.

De la Hera, T. 2017. Persuasive gaming: Identifying the different types of persuasion through games. International Journal of Serious Games 4(1): 31-39.

Deepend. 2005. Food Force. [browser]. United Nations World Food Programme. Game.

Ekman, J., and E. Amnå. 2012. Political participation and civic engagement: Towards a new typology. Human Affairs 22 (3): 283-300.

Frasca, G. 2003a. September $12^{\text {th }}$. [browser]. Newsgaming. Game.

- 2003b. Simulation versus narrative. Introduction to ludology. In The Video Game Theory Reader, eds. M. Wolf and B. Perron, 221-236. New York: Routledge.

Frissen, V., S. Lammes, M. de Lange, J. de Mul, and J. Raessens, eds. 2015. Playful identities: The ludification of digital media cultures. Amsterdam: Amsterdam University Press. 
Gainous, J., and K. M. Wagner. 2014. Tweeting to power: The social media revolution in American politics. London: Oxford University Press.

GameTheNews. 2013. Endgame: Syria. [browser/Android/iOS]. Game.

Gee, J. P. 2007. Good video games, good learning: Collected essays on video games, learning, and literacy. New York: Peter Lang Publishing Inc.

Goris, J., M. B. Jalink, and H. O. ten Cate Hoedemaker. 2014. Training basic laparoscopic skills using a custom-made video game. Perspectives on Medical Education 3:314-318.

Honohan I. 2002. Civic republicanism. London: Routledge.

Hoskins, B., E. Villalba, and M. Saisana. 2012. The 2011 civic competence composite indicator (CCCI-2): Measuring young people's civic competence across Europe based on the IEA international citizenship and civic education study. Luxembourg: Publication office of the European Union.

Huntemann, N. B., and M. T. Payne, eds. 2010. Joystick soldiers: The politics of play in military video games. New York: Routledge.

iMinds. 2010. Poverty Is Not a Game. [browser]. Game. interFUEL. 2006. Darfur is Dying. [browser]. mtvU. Game.

Ito, M., J. Antin, M. Finn, A. Law, A. Manion, S. Mitnick, D. Schlossberg, S. Yardi, and H. A. Horst. 2009. Hanging out, messing around, and geeking out: Living and learning with new media. Cambridge, MA: The MIT Press. Jacobs, R. S. 2016. Play to win over: Effects of persuasive games. Psychology of Popular Media Culture. http://psycnet.apa.org/doi/10.1037/ ppmoooo124.

Jacobs, R. S., J. Jansz, and T. de la Hera. 2017. The key features of persuasive games: A model and case analysis. In New perspectives on the social aspects of digital gaming: Multiplayer 2, eds. R. Kowert and T. Quandt, 153-171. New York: Routledge.

Jang, Y., and S. Ryu. 2011. Exploring game experiences and game leadership in massively multiplayer online role-playing games. British Journal of Educational Technology 42 (4): 616-623.

Jansz, J. 2005. The emotional appeal of violent video games for adolescent males. Communication Theory 15 (3): 219-241.

Jenkins, H. 2006. Confronting the challenges of participatory culture: Media education for the twenty-first century (white paper). Chicago, IL: MacArthur Foundation Digital Media and Learning Program.

Jenkins, H., and N. Carpentier. 2013. Theorizing participatory intensities: A conversation about participation and politics. Convergence: The International Journal of Research into New Media Technologies 19 (3): 265-286. Jenkins, H., M. Ito, and d. boyd. 2016. Participatory culture in a networked era. Malden, MA: Polity Press. 
Kaase, M., and K. Newton, eds. 1995. Beliefs in government. Oxford: Oxford University Press.

Kahne, J., E. Middaugh, and C. Evans. 2009. The civic potential of video games. Cambridge, MA: The MIT Press.

Kerr, D., L. Sturman, W. Schulz, and B. Burge. 2009. ICCS 2009 European report. Civic knowledge, attitudes, and engagement among lower-secondary students in 24 European countries. Amsterdam: IEA.

Kligler-Vilenchik, N., and S. Shresthova. 2012. Learning through practice: Participatory culture civics. MacArthur Foundation. http://ypp.dmlcentral. net/sites/all/files/publications/Learning\%2oThrough\%2oPractice_KliglerShresthova_Oct-2-2012.pdf.

-. 2014. "Feeling that you are doing something": Participatory culture civics. Conjunctions. Transdisciplinary Journal of Cultural Participation 1 (1). http://www.conjunctions-tjcp.com/article/view/18604.

Klofstad, C. A. 2011. Civic talk: Peers, politics, and the future of democracy. Philadelphia, PA: Temple University Press.

Le Diberder, A., and F. Le Diberder. 1998. L'univers des jeux vidéo. Paris: La Découverte.

Levine, P., and H. M. Lopez. 2002. Youth voter turnout has declined, by any measure. Center for Information and Research on Civic Learning and Engagement. http://civicyouth.org/research/products/Measuring_Youth_Voter_Turnout.pdf.

Lieberman, D. A. 2006. What can we learn from playing interactive games? In Playing video games: Motives, responses, and consequences, eds. P. Vorderer and J. Bryant, 379-395. Mahwah, NJ: Lawrence Erlbaum.

Lin, W. Y., P. H. Cheong, Y. C. Kim, and J. Y. Jung. 2010. Becoming citizens: Youths' civic uses of new media in five digital cities in East Asia. Journal of Adolescent Research 25 (6): 839-857.

Lopez, H. M., and C. Donovan. 2002. Youth and adult voter turnout from 1972- 2002. Center for Information and Research on Civic Learning and Engagement. http://www.civicyouth.org/PopUps/FactSheets/FS_Youth\%20 turnout1972_2002.pdf.

McKinney, Urban Ministries of Durham 2011. Spent. Game.

Mitgutsch, K. 2011a. Playful learning experiences. Meaningful learning patterns in players' biographies. International Journal of Gaming and Computer-Mediated Simulations 3 (3): 54-68.

- $2011 \mathrm{~b}$. Serious learning in serious games. Transformative learning in video games. In Serious games and edutainment applications, eds. M. Ma, A. Oikonomou, and L. C. Jain, 45-58. New York: Springer.

Molleindustria. 2006. McDonald's Video Game. [browser]. Molleindustria. Game. 
Neys, J. 2014. Social media political gaming. In Sage encyclopedia of social media and politics, ed. K. Harvey, 1171-1173. London: Sage Publications.

Neys, J., F. de Grove, J. van Looy, and J. Jansz. 2012. Poverty is not a game: Behavioral changes and long-term effects after playing PING. In Proceedings of the 62nd annual conference of the International Communication Association, Phoenix, May 24-28, 2012.

Neys, J., and J. Jansz. 2010. Political internet games: Engaging an audience. European Journal of Communication 25 (3): 227-241.

Norris, P. 2002. Democratic phoenix: Reinventing political activism. New York: Cambridge University Press.

Peng, W., M. Lee, and C. Heeter. 2010. The effects of a serious fame on roletaking and willingness to help. Journal of Communication 60 (4): 723-742. Persuasive Games. 2003. The Howard Dean for Iowa Game. [browser]. Game. Prensky, M. 2005. Computer games and learning: Digital game-based learning. In Handbook of computer game studies, eds. J. Raessens and J. H. Goldstein, 97-122. Cambridge, MA: The MIT Press.

Putnam, R. D. 2000. Bowling alone: The collapse and revival of American democracy. New York: Simon and Schuster.

Raessens, J. 2006. Playful identities, or the ludification of culture. Games and Culture 1 (1): $5^{2-57}$.

- 2014. The ludification of culture. In Rethinking gamification, eds. M. Fuchs, S. Fizek, P. Ruffino, and N. Schrape, 91-114. Lüneburg: meson press.

- 2015. Playful identity politics: How refugee games affect the player's identity. In Playful identities: The ludification of digital media cultures, eds. V. Frissen, S. Lammes, M. de Lange, J. de Mul, and J. Raessens, 245-26o. Amsterdam: Amsterdam University Press.

- 2016. Game studies. In The international encyclopedia of communication theory and philosophy, eds. K. B. Jensen, R. T. Craig, J. D. Pooley, and E. W. Rothenbuhler, 1-5. Hoboken, NJ: Wiley.

Raessens, J., and J. Goldstein, eds. 2005. Handbook of computer game studies. Cambridge, MA: The MIT Press.

Rainie, L., A. Smith, K. L. Schlozman, H. Brady, and S. Verba. 2012. Social media and political engagement. PEW Research Center. http://pewinternet. org/Reports/2012/Political-Engagement.aspx.

Raphael, C., C. Bachen, K. M. Lynn, J. Baldwin-Philippi, and K. A. McKee. 2010. Games for civic learning: A conceptual framework and agenda for research and design. Games and Culture 5 (2): 199-235.

Raphael, C., C. Bachen, and P. F. Hernández-Ramos. 2012. Flow and cooperative learning in civic game play. New Media \& Society 14 (8): 1321-1338.

Rawlings, T. 2012. My Cotton Picking Life. [browser]. GameTheNews. Game. 
Realtime Associates. 2006. Re-Mission. [Windows]. HopeLab. Game.

Ritterfeld, U., M. Cody, and P. Vorderer. 2009. Introduction. In Serious games: Mechanisms and effects, eds. U. Ritterfeld, M. Cody, and P. Vorderer, 3-10. New York: Routledge.

Ritterfeld, U., and R. Weber. 20o6. Video games for entertainment and education. In Playing video games: Motives, responses, and consequences, eds. P. Vorderer and J. Bryant, 399-413. Mahwah, NJ: Lawrence Erlbaum.

Ruggiero, D. 2015. The effect of playing a persuasive game on attitude and affective learning. Computers in Human Behavior 45:213-221.

Schols, M. 2015. Young, online and connected. PhD thesis Erasmus University Rotterdam.

Smith, A. 2013. Civic engagement in the digital age. PEW Research Center: http://pewinternet.org/Reports/2013/Civic-Engagement.aspx.

Squire, K. 2007. Games, learning, and society: Building a field. Education Technology 47 (5): 514 .

Squire, K., and H. Jenkins. 2003. Harnessing the power of games in education. Insight 3 (1): 5-33.

Steinkuehler, C. A. 2005. Cognition and learning in massively multiplayer online games: A critical approach (Doctoral dissertation). Available from ProQuest Dissertations and Theses database (UMI No. 982810331).

Stolle, D., and M. Hooghe. 2005. Inaccurate, exceptional, one-sided or irrelevant? The debate about the alleged decline of social capital and civic engagement in western societies. British Journal of Political Science 35 (1): 149-167.

Thorson, K., K. Driscoll, B. Ekdale, S. Edgerly, L. Gamber Thompson, A. Schrock, L. Swartz, E. K. Vraga, and C. Wells. 2013. YouTube, Twitter and the Occupy movement: Connecting content and circulation practices. Information, Communication \& Society 16 (3): 421-451.

United States Army. 2002. America's Army. [Windows/PS4]. United States Army. Game.

Verba, S., K. Schlozman, and H. Brady. 1995. Voice and equality: Civic voluntarism in American politics. Cambridge, MA: Harvard University Press.

Waddington, D. I. 2013. A parallel world for the World Bank: A case study of Urgent: Evoke, an educational alternate reality game. Revue Internationale des Technologies en Pédagogie Universitaire 10:42-56.

Wattenberg, M. 2002. Where have all the voters gone? Cambridge, MA: Harvard University Press.

Whitton, N., and P. Hollins. 2008. Collaborative virtual gaming worlds in higher education. ALT-J, Research in Learning Technology 16 (3): 221-229. 


\section{About the authors}

Jeroen Jansz holds the Chair of Communication and Media in the Department of Media \& Communication at Erasmus University Rotterdam. He is a member of the Erasmus Research Centre for Media, Communication, and Culture. His research is about the reception of new media. The appeal of digital games is a long-standing research interest. He is co-founder of the Game Studies Division in the International Communication Association, a member of PEGI's expert group (Pan European Game Information) and President of NeFCA, the Netherlands Flanders Communication Association.

Joyce Neys is a PhD candidate at the Erasmus Research Centre for Media, Communication and Culture at Erasmus University Rotterdam. She is currently working on the research project Empowered citizens: How new media facilitate civic engagement under supervision of Prof. Jeroen Jansz. The project investigates how citizens use different forms of new media as a political tool. In particular, she is interested in citizens who create their own media content, such as online political video games, political remix videos, and political machinimas. Neys is also a lecturer in the International Bachelor Communication and Media program at Erasmus University Rotterdam where she teaches statistical analysis and new media and civic engagement. 